\title{
The Influence of Fuel and Steam Consumption on Characteristics of Fixed Bed Process of Woody Biomass Steam Gasification with Intensive Heat Supply
}

\author{
I. G. Donskoy*
}

Melentiev Energy Systems Institute of Siberian Branch of Russian Academy of Sciences, Irkutsk, Russia

\begin{abstract}
Plant biomass is one of the most widespread renewable energy sources. Energy utilization of biomass allows solving some problems associated with the development of off-grid energy systems and the processing of combustible waste (primarily agricultural and forestry waste). This paper is devoted to the study of an allothermal gasification process of plant biomass materials using a kinetic-thermodynamic model developed by the author. The gasification process is considered stationary, and steam is used as a gasification agent. The power of the supplied heat is considered constant $(10 \mathrm{~kW})$. One of the significant tasks related to allothermal gasification is to choose flowrate parameters so that the heat supplied is efficiently used in chemical reactions without the threat of reactor overheating. The determination of the boundaries of the safe gasifier operation involved variant calculations with a view to optimizing the gasification conditions. The calculation results show that the allothermal gasification process can proceed with a thermochemical efficiency of about $\mathbf{7 0 \%}$. For each fixed fuel consumption level, there is an optimal fuel-steam ratio. The complete conversion of biomass requires sufficiently high temperatures. The produced gas contains a significant steam fraction (>50 vol\%) even under optimal conditions. The calculated fraction of hydrogen in dry gas is up to $60 \mathrm{vol} \%$. The data obtained can be used to assess the efficiency of energy units with biomass gasification using
\end{abstract}

\footnotetext{
* Corresponding author.

E-mail: donskoy.chem@mail.ru
}

http://dx.doi.org/10.38028/esr.2020.04.0002

Received October 09, 2020. Revised October 21, 2020.

Accepted November 03, 2020. Available online February 01, 2021.

This is an open access article under a Creative Commons Attribution-NonCommercial 4.0 International License.

(C) 2020 ESI SB RAS and authors. All rights reserved. high-temperature sources, for example, in systems that use and store solar thermal energy.

Index Terms: bioenergy, allothermal gasification, mathematical modeling, hydrogen, solar energy.

\section{INTRODUCTION}

Thermochemical biomass conversion technologies have prospects for being used in distributed generation systems, not only in agricultural regions, where a large quantity of cheap reserves of combustible waste is available [1, 2] but also in developed countries, where renewable energy sources are attractive due to their environmental characteristics [3, 4]. The significant energy potential of biomass (primarily forestry and agriculture waste) is currently used to an extremely small extent, although it can be technically and economically beneficial for a wide range of energy systems $[5,6]$. Biomass is used both as an addition to fossil fuels to reduce hazardous emissions produced [7, 8] and as the primary fuel [9]. The involvement of biomass in energy production requires new methods and modification of the known methods of its thermochemical processing. The reliable technologies based on these methods can only be created through an in-depth scientific study of all stages of the process, from the selection of suitable raw materials to the control of processes in the reactor and design of cleaning systems $[10,11]$.

Biomass is characterized by a high moisture content, high reactivity (compared to fossil fuel), the variability of mechanical properties (biomass particles may agglomerate [12], or, vice versa, disintegrate during thermal conversion [13]), production of significant amounts of tarry products during heating and oxidation [14], and a low content of ash (which, however, often has increased corrosive properties and a tendency to form fine particulate matter $[10,15])$. Combustion (including co-combustion) is the most widely 
used biomass conversion technology [16]. Many processes of low-temperature thermochemical processing of biomass with the production of high-calorific gas through pyrolysis and gasification have been proposed [17, 18], but their efficiency is very sensitive to the conditions of their implementation. There are more specific conversion processes, for example, plasma processing [19], and the use of supercritical fluids [20]. However, they are technologically more complicated and have high energy demands.

Pyrolysis and gasification of biomass have the potential to be applied in the areas with low energy consumption, in decentralized power supply systems. Researchers tend to consider low-capacity power units [21, 22], working with internal combustion engines [23, 24], microturbines [25], fuel cells [26], or gas burners [27]. Analysis of the life cycle of bioenergy units, even for small capacities, shows their high environmental efficiency compared to the units using fossil fuels [28, 29]. Gasification efficiency in typical small-scale processes (fixed bed and fluidized bed) is about $50-70 \%$. Given the thermal efficiency of the gas engine at the level of $20-30 \%$, one can obtain fuel utilization efficiency of $10-20 \%$. One of the ways to improve the efficiency of gasification-based energy units is to use external heat sources to enhance conditions in the reactor.

Solar radiation is usually concentrated using collectors [30-32], which allow reaching a peak thermal power of up to $100 \mathrm{MW}$ with a radiation collection efficiency of the order of several tens of $\mathrm{W} / \mathrm{m}^{2}$. The use of biomass makes it possible to smooth stochastic generation as part of hybrid power plants $[33,34]$. The processes of thermochemical conversion of biomass can be used to store the energy of solar radiation (along with electric batteries [35, 36], carbonate and oxide cycles [37, 38], and others). To this end, fixed or fluidized bed reactors and vortex devices were developed [39-41]. The gasification agent is usually steam or vapor-air mixtures $[42,43]$. The produced combustible gas with high hydrogen content can be used for direct oxidation or stored in a gasholder [44, 45]. Concentrated solar radiation can also be used at thermal power plants with solid fuel processing, for example, for heating of working fluid [46] or air when burning low-calorific fuels [47].

Experimentally, biomass and coal gasification and combustion under the intense radiation were investigated in [48-50]. The conversion factor of radiant energy in the biomass gasification process is usually low (10-20\%). Kinetics of gasification of carbonaceous materials at high temperatures was studied in $[51,52]$. Mathematical models of gasification processes under the influence of solar radiation are proposed in [53-58]. Allothermal processes of biomass pyrolysis and gasification were investigated in [59-67], including those in a staged gasification unit [68, 69]. Schemes with the heat recirculation of the produced gas were proposed in [70]. Mathematical models of allothermal reactors were proposed in [71-75]. This study considers a version of the model [74] with fuel and steam heating by a constant heat flow. The gasification process is optimized by direct calculation of an output parameters on a grid of input parameters and selection of the best parameters according to efficiency criteria (completeness of fuel conversion, hydrogen yield) under some constraints (for example, on the maximum temperature). The computational efficiency of the mathematical model allows making such calculations in a reasonable time.

\section{MATHEMATICAL MODEL DESCRIPTION AND INITIAL DATA}

The equations describing stationary heat transfer in the fuel bed can be written as follows:

$$
\begin{gathered}
\lambda^{g} \frac{d^{2} T^{g}}{d z^{2}}-C_{p}^{g} J^{g} \frac{d T^{g}}{d z}-\alpha_{1} S_{1}\left(T^{g}-T^{f}\right)- \\
-\alpha_{2} S_{2}\left(T^{g}-T^{w}\right)+q^{g}(z)=0, \\
\lambda^{f} \frac{d^{2} T^{f}}{d z^{2}}-C_{p}^{f} J^{f} \frac{d T^{f}}{d z}+\alpha_{1} S_{1}\left(T^{g}-T^{f}\right)- \\
-\alpha_{3} S_{2}\left(T^{f}-T^{w}\right)+q^{f}(z)=0, \\
\frac{d^{2} T^{2}}{d z^{2}}+\alpha_{2} S_{2}\left(T^{g}-T^{w}\right)+\alpha_{3} S_{2}\left(T^{f}-T^{w}\right)+q^{w}(z)=0 .
\end{gathered}
$$

Here $T$ is temperature, $\mathrm{K} ; C_{p}$ is heat capacity, $\mathrm{J} / \mathrm{kg} / \mathrm{K}, \lambda$ is effective thermal conductivity, $\mathrm{W} / \mathrm{m} / \mathrm{K} ; \alpha$ is heat transfer coefficient, $\mathrm{W} / \mathrm{m}^{2} / \mathrm{K} ; J$ is flowrate, $\mathrm{kg} / \mathrm{m}^{2} / \mathrm{s} ; S_{1}$ is gas-fuel heat transfer surface, $\mathrm{m}^{2} / \mathrm{m}^{3} ; S_{2}$ is gas-wall heat transfer surface, $\mathrm{m}^{2} / \mathrm{m}^{3} ; q$ is a heat source, $\mathrm{W} / \mathrm{m}^{3} ; z$ is spatial coordinate (reaction zone length), $\mathrm{m}$; indexes $f, g$, and $w$ correspond to fuel, gas and wall.

When solving the problem numerically, the reactor is divided along the axis into some small-volume elements. Knowing the residence time of the gas in each of these elements, one can write the function of the heat source for the selected $i$-th element in the form:

$$
q=Q_{d r y} r_{d r y}+Q_{p y r} r_{p y r}+Q_{g a s} r_{g a s}
$$

Here $Q$ is a thermal effect, $\mathrm{J} / \mathrm{kg} ; r$ is process rate, $\mathrm{kg}$ / $\mathrm{m}^{3} / \mathrm{s}$; indexes $d r y$, pyr, and gas correspond to drying, pyrolysis, and char gasification processes, respectively. Values of $q$ could be calculated using enthalpies of individual components and mass balance for every spatial element of length $\Delta z$ :

$$
q_{i}=\frac{J_{i-1}}{\Delta z} \sum_{j} h_{i-1}^{j}\left(T_{i-1}\right) y_{i-1}^{j}-\frac{J_{i}}{\Delta z} \sum_{j} h_{i}^{j}\left(T_{i}\right) y_{i}^{j} .
$$

Here index $i$ corresponds to spatial element number; $h^{j}$ is specific enthalpy of $j$-th component, $\mathrm{J} / \mathrm{kg} ; y^{j}$ is the mass fraction of $j$-th component.

The change in the chemical composition is calculated in two steps. The first step suggests considering heterogeneous processes: drying, pyrolysis, and the charcoal reactions with $\mathrm{CO}_{2}$ and $\mathrm{H}_{2} \mathrm{O}$ (oxidation by $\mathrm{O}_{2}$ is not taken into account): 


$$
\begin{gathered}
\frac{d y_{\mathrm{H}_{2} \mathrm{O}}}{d z}=\frac{\rho^{g}}{J^{g}} \beta S_{1}\left(\frac{C_{\mathrm{H}_{2} \mathrm{O}}^{e q}}{\rho^{g}}-y_{\mathrm{H}_{2} \mathrm{O}}\right), \\
\frac{d m_{V}}{d z}=-\frac{\rho^{f}}{J^{f}} k_{p y r} m_{V}, \\
\frac{d m_{C}}{d z}=\frac{1-V_{d a f}}{V_{d a f}} \frac{d m_{V}}{d z}+\frac{\rho^{f}}{J^{f}}\left(-k_{\mathrm{CO}_{2}}^{e f f} S_{1} \rho_{g} y_{\mathrm{CO}_{2}}-k_{\mathrm{H}_{2} \mathrm{O}}^{e \text { eff }} S_{1} \rho_{g} y_{\mathrm{H}_{2} \mathrm{O}}\right) .
\end{gathered}
$$

Here $\rho$ is the density, $\mathrm{kg} / \mathrm{m}^{3} ; \beta$ is coefficient of mass transfer, $\mathrm{m} / \mathrm{s} ; C^{e q}$ is the equilibrium concentration of water vapors, $\mathrm{kg} / \mathrm{m}^{3} ; k_{p y r}$ is pyrolysis rate constant, $s^{-1} ; m_{V}$ is the quantity of volatiles in the fuel, $\mathrm{kg} ; m_{C}$ is the amount of carbon in the fuel, $\mathrm{kg} ; y_{\mathrm{CO}_{2}}, y_{\mathrm{H}_{2} \mathrm{O}}$ are mass fractions of gasification agents in the porous volume; $k^{\text {eff }}$ is the effective rate constant of a heterogeneous reaction, $\mathrm{m} / \mathrm{s}$. The effective rate constant of the heterogeneous reaction $k^{\text {eff }}$ is determined in the quasi-stationary approximation [76]:

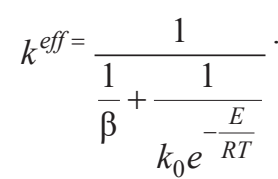

Here $k_{0}$ is the pre-exponential factor, $\mathrm{m} / \mathrm{s} ; E$ is the activation energy, $\mathrm{J} / \mathrm{mol} ; R$ is the universal gas constant. Chemical kinetics of reactions in the gas phase is not considered: it is assumed that the gas phase quickly reaches a state of equilibrium. Thus, at the second step of the calculation, chemical transformations are described using a thermodynamic model with macrokinetic constraints on the rate of heterogeneous transformations. This approach is applicable to high-temperature processes, in which the rate of gas-phase processes is quite high, compared to that of heterophase processes. In the iterations, the local temperature can be considered a constant parameter, and the heat balance is taken into account when solving the heat transfer equations [77]. Kinetic coefficients are presented in Table 1.
Table 1. Kinetic coefficients

\begin{tabular}{ccc}
\hline \hline Reaction & $k_{0}, \mathrm{~s}^{-1}$ & $E_{a}, \mathrm{~kJ} / \mathrm{mol}$ \\
\hline Pyrolysis & $5 \times 10^{4}$ & 96 \\
\hline $\mathrm{C}+\mathrm{CO}_{2}$ & $1.32 \times 10^{7}$ & 250 \\
\hline $\mathrm{C}+\mathrm{H}_{2} \mathrm{O}$ & $9.3 \times 10^{5}$ & 175 \\
\hline \hline
\end{tabular}

The presented model of a fixed bed conversion was used earlier in the study on low-grade fuels gasification processes in $[78,79]$. This research assumes that the reaction zone of the reactor is uniformly heated through the wall with a constant heat flux of $10 \mathrm{~kW}$. The reaction zone dimensions taken for calculations are - length is $0.25 \mathrm{~m}$ and diameter is $0.2 \mathrm{~m}$. The fuel is woody biomass with the following composition: $W^{r}=12 \%, A^{d}=0.67 \%$, $V^{\text {daf }}=80 \% C^{\text {daf }}=46.96 \%, H^{d a f}=5.92 \% ; O^{d a f}=45.23 \%$; $N^{d a f}=1.08 \% ; S^{d a f}=0.08 \%$; average particle size is $2.5 \mathrm{~cm}$. Variable parameters are fuel flowrate $(4-10 \mathrm{~kg} / \mathrm{h})$ and steam flowrate $(2-10 \mathrm{~kg} / \mathrm{h})$. The fuel inlet temperature is $300 \mathrm{~K}$, the steam inlet temperature is $600 \mathrm{~K}$. The characteristics of interest are the outlet gas composition, the degree of fuel conversion, and the thermochemical efficiency of the process $(\eta)$. Efficiency is defined as the ratio of the output flow of chemical energy (calorific value of the generator gas $Q^{g} J^{g}$ ) to the input flow of energy (calorific value of the fuel $Q^{f} J^{f}$ and supplied heat $q^{e x}$ ):

$$
\eta=\frac{Q^{g} J_{o u t}^{g}}{Q^{f} J_{i n}^{f}+q^{e x}} .
$$

The calorific value of the generator gas is calculated as the weighted sum of the calorific values of its constituent components. With a higher calorific value of the feedstock of about $15 \mathrm{MJ} / \mathrm{kg}$, the supplied heat is equivalent to $25-$ $60 \%$ of the calorific value of the biomass entering the reactor.

\section{RESULTS AND DISCUSSION}

At low biomass and steam flowrates, most of the supplied heat goes to temperature increase: as seen in

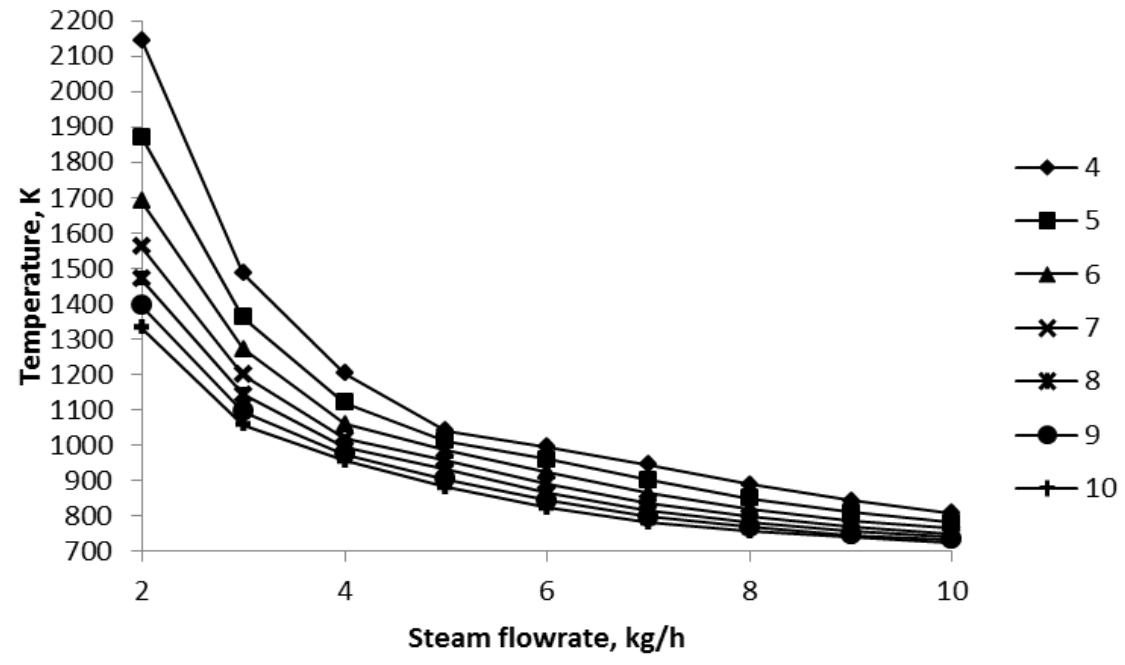

Fig. 1. Relationship between maximum temperature in gasifier and steam and fuel flow rates (numbers in the legend are fuel flowrates, $\mathrm{kg} / \mathrm{h}$ ). 


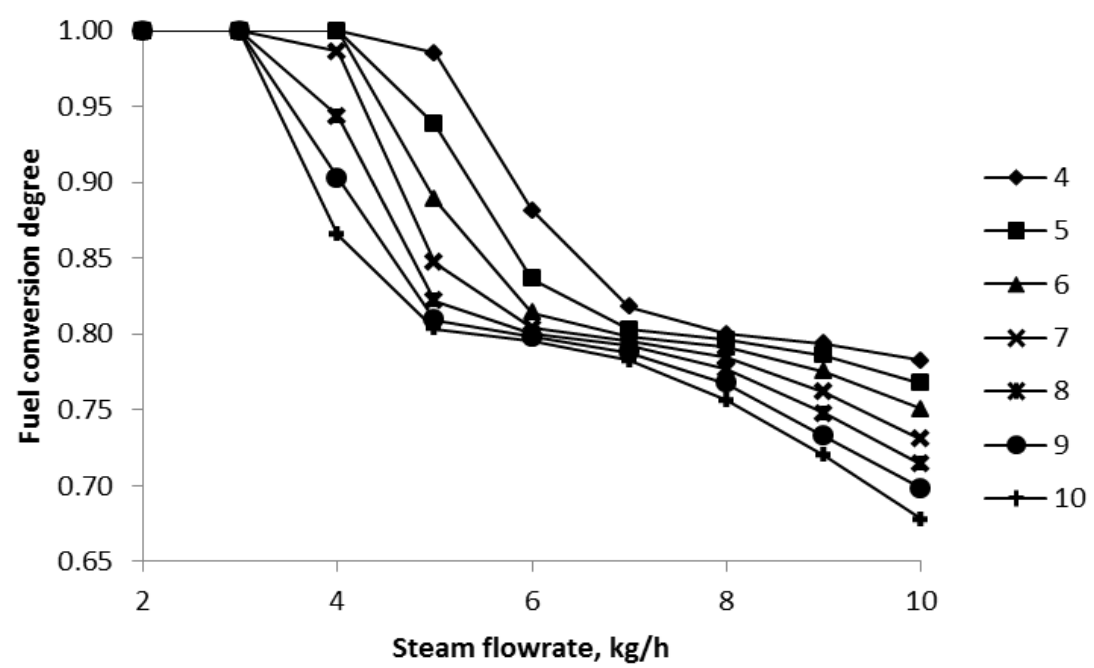

Fig. 2. Relationship between fuel conversion degree and steam and fuel flowrates (numbers in the legend are fuel flowrates, $\mathrm{kg} / \mathrm{h}$ ).

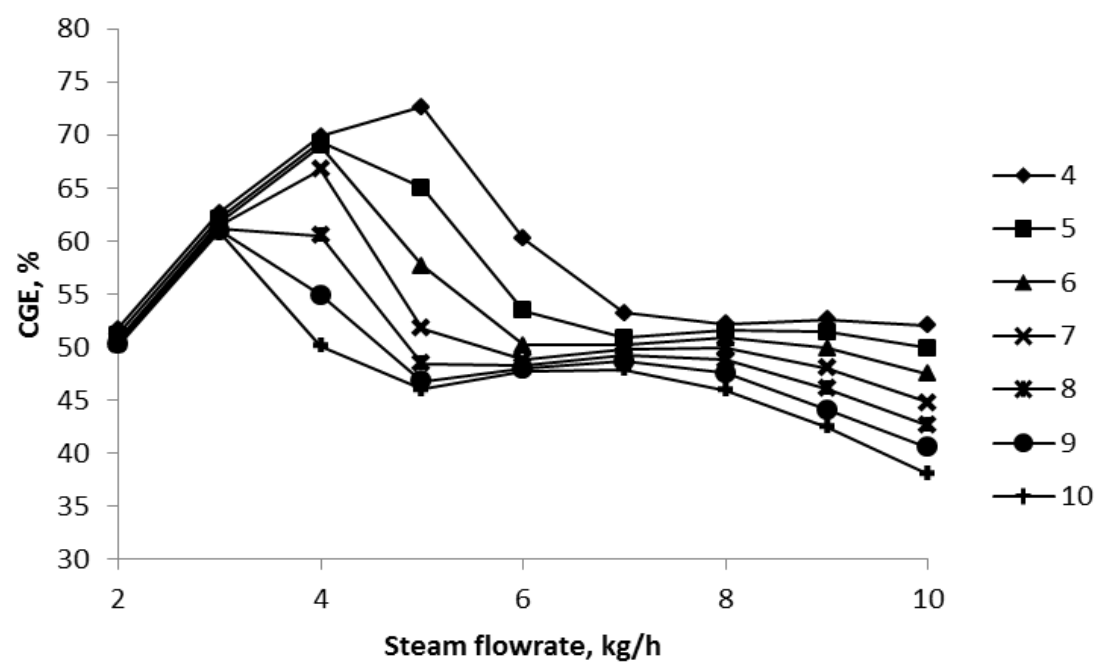

Fig. 3. Relationship between thermochemical efficiency of gasification process and steam and fuel flowrates (numbers in the legend are fuel flowrates, $\mathrm{kg} / \mathrm{h}$ ).

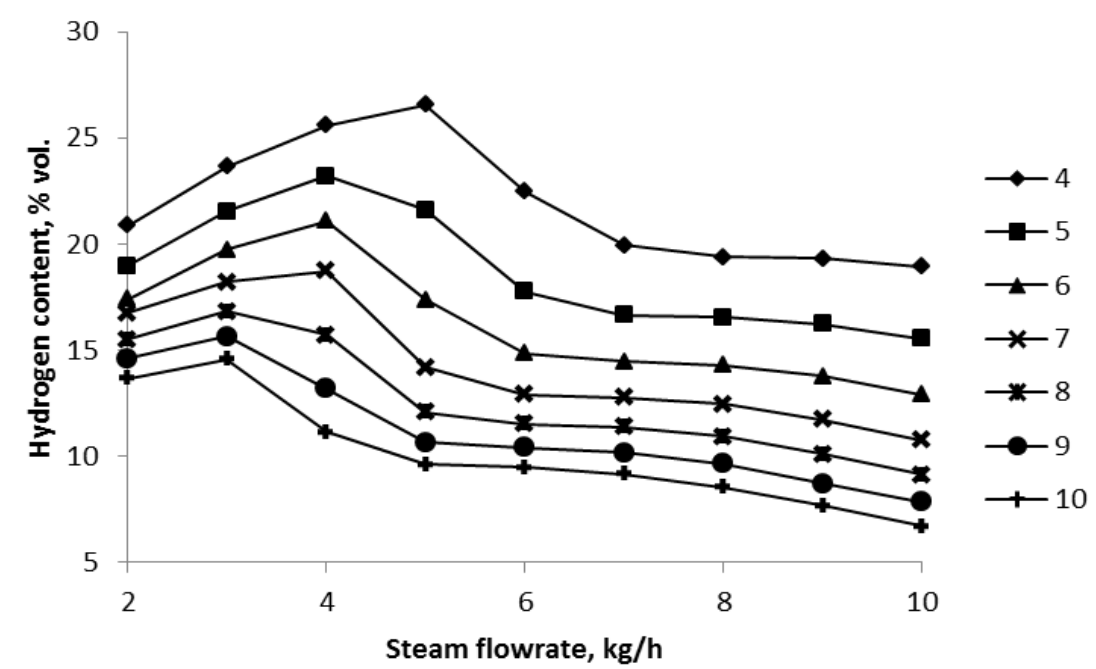

Fig. 4. Relationship between hydrogen concentration in raw produced gas and steam and fuel flowrates (numbers in the legend are fuel flowrates, $\mathrm{kg} / \mathrm{h}$ ). 


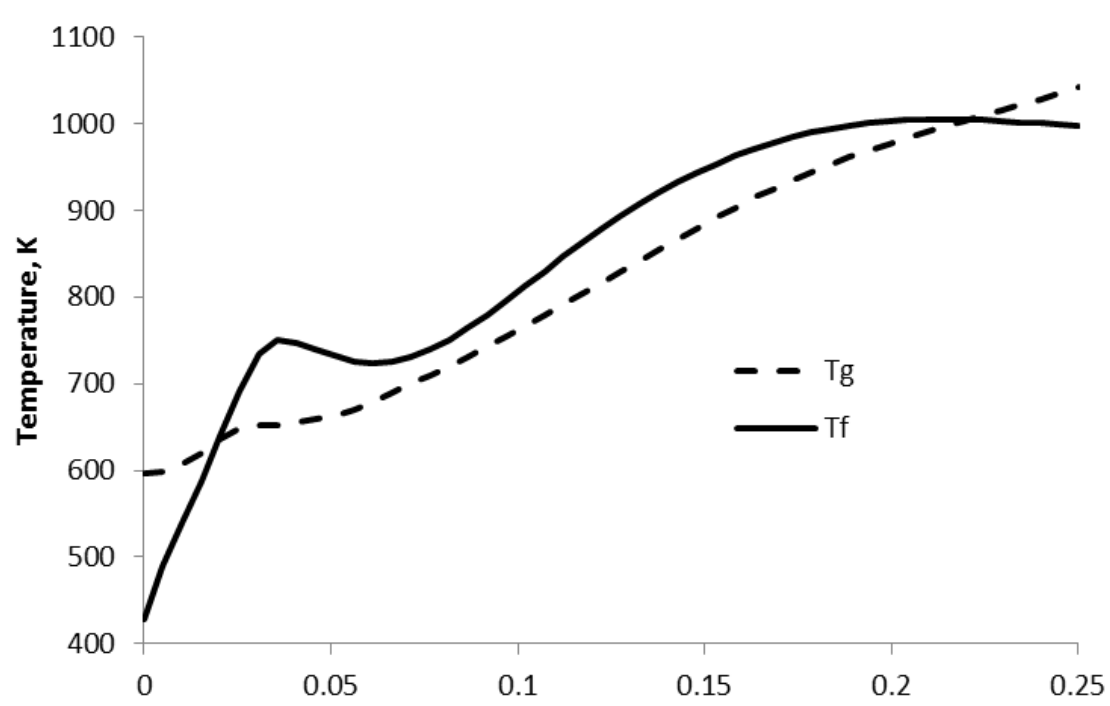

Fig. 5. Distribution of gas and fuel temperature along the reaction zone.

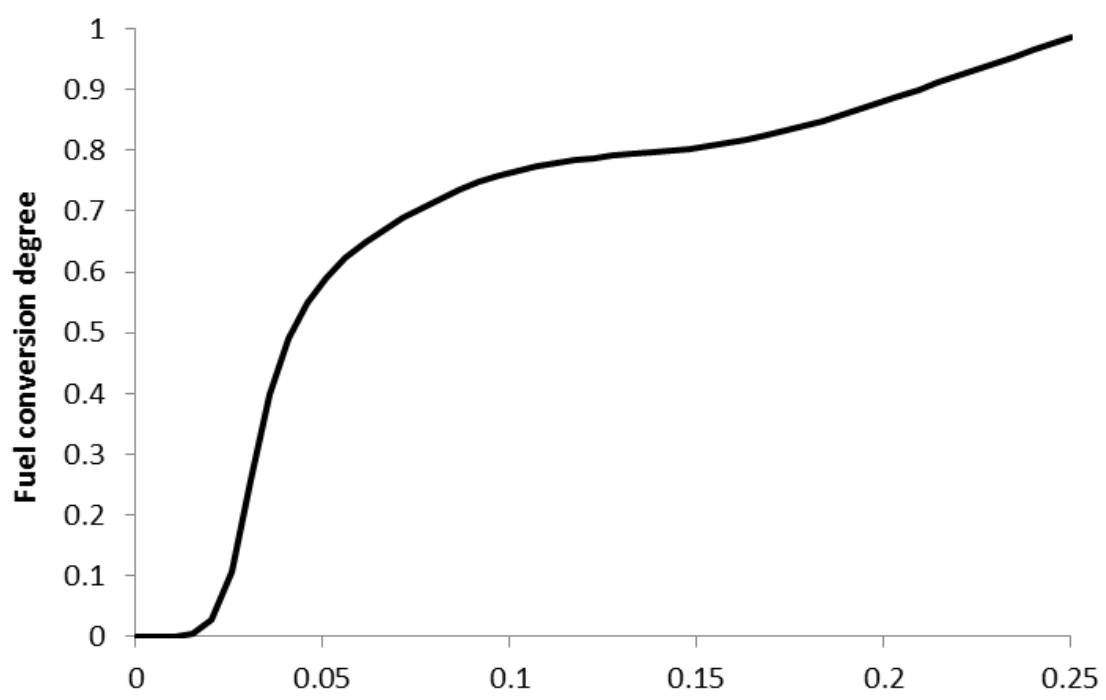

Fig. 6. Distribution of fuel conversion degree along the reaction zone.

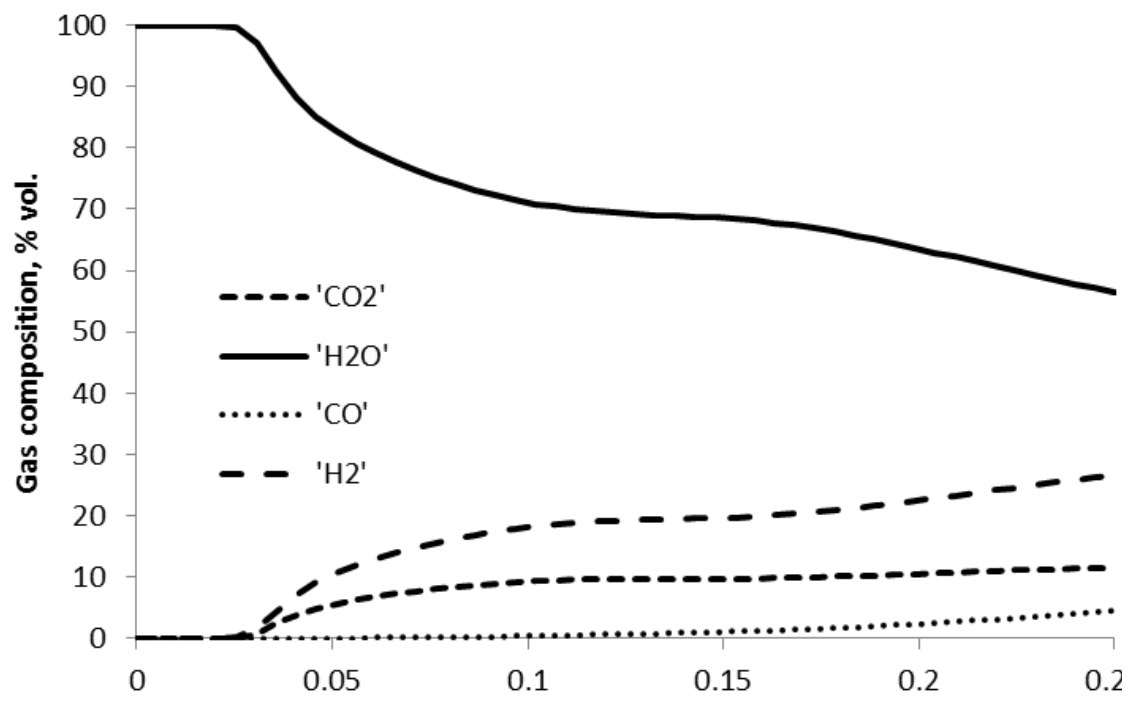

Fig. 7. Distribution of gas composition along the reaction zone. 
Table 2. Comparison of modeling results with published data on dry gas composition (vol\%.)

\begin{tabular}{cccccccc}
\hline \hline & Source & & $\mathrm{H}_{2}$ & $\mathrm{CO}$ & $\mathrm{CO}_{2}$ & $\mathrm{CH}_{4}$ \\
\hline & {$[82]$} & & 44.7 & 25.2 & 5.8 & 1.8 \\
\hline \multirow{2}{*}[83]{} & & Pyrolysis & 44.2 & 51.8 & 18.3 & 23.8 \\
\cline { 3 - 8 } & & Gasification & 48.8 & 32.8 & 16.7 & 1.7 \\
\hline & {$[49]$} & & 52.4 & 38.9 & 3.2 & 1.5 \\
\hline \multirow{2}{*}{$\begin{array}{c}\text { Present } \\
\text { work }\end{array}$} & {$[67]$} & & 44.6 & 19.7 & 22.3 & 13.4 \\
\hline & {$[40]$} & & 37.2 & 40.0 & 11.1 & 8.8 \\
\hline \hline
\end{tabular}

Fig. 1, temperatures can reach very high values (up to $2000 \mathrm{~K})$. These conditions are not suitable for real units due to constraints on material properties. Additionally, the kinetics of chemical reactions and transport processes at high temperatures may differ from that assumed in the model. Already in this stage of consideration, it is possible to exclude a range of inappropriate parameters.

With an increase in the fuel and steam flowrate, however, the conversion of fuel decreases (Fig. 2). The lower the temperature, the lower the gasification rate, which is why, at a steam flowrate of more than $3-4 \mathrm{~kg} / \mathrm{h}$, charcoal yield increases sharply. At a high fuel flowrate, the reactor can operate as a pyrolyzer (for example, for the production of activated carbon [80]). For complete gasification of biomass, it is necessary to select conditions with low fuel flowrates and high steam flowrates, most of which serves as ballast to prevent overheating. Fig. 3 shows the relationship between the efficiency and the process parameters: with a change in the steam flowrate and fixed fuel flowrate, the gasification process efficiency has an extremum corresponding to the complete conversion of fuel carbon. The maximum concentration of hydrogen in the produced gas is also observed (about 26 vol\%).

Thus, with a fixed external heat supply, the optimal parameters of the allothermal gasification process are determined by the fuel-steam ratio and the total flowrate of reagents (at low flowrates, the temperature in the reactor becomes unacceptably high). The range of suitable temperatures, in which the gasification reactions proceed quite intensively, can be limited, but the reactor overheating is not observed in a range of 1000-1100 K. Then, according to Fig. 1, one can cut off the area of unsuitable conditions.

The temperature distribution over the reactor length for one set of parameters (fuel flowrate $4 \mathrm{~kg} / \mathrm{h}$ and steam flowrate $5 \mathrm{~kg} / \mathrm{h}$ ) is shown in Fig. 5. The fuel is heated at an almost constant rate until intense devolatilization begins.

As seen in Fig. 6, with an increase in the degree of conversion, the devolatilization slows down. The gasification stage begins approximately in the middle of the bed but has enough time to complete. The gas composition is shown in Fig. 7: an excess of water vapor leads to a shift in the equilibrium in the water-gas reaction towards the formation of hydrogen and carbon dioxide, $\mathrm{CO}$ is formed only at the gasification region, and its fraction in gas is very low $(4.5 \mathrm{vol} \%)$. If the produced gas is dried by cooling and complete condensation of water vapors, then hydrogen content in it can reach $60 \%$. Some of the hydrogens, however, will be converted into a water shift reaction $\left(\mathrm{CO}_{2}+\mathrm{H}_{2}=\mathrm{H}_{2} \mathrm{O}+\mathrm{CO}_{2}\right)$.

Fuel gasification using concentrated solar radiation, in reality, occurs with significant fluctuations of heat flow even at short times, which is associated with the natural variability of atmospheric conditions. Therefore, for a more accurate assessment of the efficiency of such processes, it is necessary to take into account the variable nature of heat supply. Another disadvantage of the model is the absence of tar in the gasification products: according to experimental data on allothermal gasification, the tar yield can be up to $45 \%$ per organic mass [81]. These problems are to be solved in further works. A comparison of the obtained results with experimental data is presented in Table 2.

It is worth noting that the experimental data are very heterogeneous: some relate to continuous reactors (mainly, fluidized bed), while others are obtained by averaging unsteady conditions. Nevertheless, the experimental data can be ranked according to their proximity to pyrolytic conditions. During biomass pyrolysis, methane content is quite high (up to 10-20 vol\%). During gasification, methane content is up to $2 \mathrm{vol} \%$. Thus, the presented simulation results are in good qualitative agreement with data on solar-driven steam gasification of biomass. The pyrolysis region is described with lower accuracy: the equilibrium model predicts an increase in the hydrogen yield with a decrease in the specific steam flowrate (due to high temperature and water vapor concentration), but experiments show an increase in the methane yield.

\section{CONCLUSION}

The present study considers a mathematical model of the biomass gasification process with steam under intensive external heat supply. It focuses on the influence of fuel and steam mass flowrates on the efficiency of the gasification process. The findings suggest that to maintain the process at a suitable temperature (i.e., to prevent overheating and provide sufficient fuel conversion), it is necessary to accurately estimate mass flowrates and a 
fuel-stream ratio. The results show that under $10 \mathrm{~kW}$ of external heat supply, suitable parameters are fuel flowrate is of $4-10 \mathrm{~kg} / \mathrm{h}$ and the steam flowrate is of $3-6 \mathrm{~kg} / \mathrm{h}$. The maximum thermochemical efficiency of the allothermal gasification process (given the heat consumption for heating the reactor) is about $70 \%$; the maximum hydrogen content in the dry produced gas is about $60 \%$. The suitable parameters for biomass gasification are in the area where the complete conversion of fuel carbon is not achieved.

\section{ACKNOWLEDGMENTS}

This work is financially supported by an international collaborative project (BRICS2019-040) under the BRICS STI Framework Programme with government funding organizations of Brazil CNPq (402849/2019-1), Russia RFBR(19-58-80016), IndiaDST(CRG/2018/004610,DST/ TDT/ TDP-011/2017), China MOST (2018YFE0183600), and South Africa NRF (BRIC190321424123). Equipment of multi-access center "High-Temperature Circuit" (ESI SB RAS) was used in this study.

\section{REFERENCES}

[1] A. S. Bisht and N. S. Thakur, "Small scale biomass gasification plants for electricity generation in India: Resources, installation, technical aspects, sustainability criteria \& policy," Renewable Energy Focus, vol. 28, pp. 112-126, 2019. DOI: 10.1016/j. ref.2018.12.004

[2] H. Li, X. Min, M. Dai, and X. Dong, "The Biomass Potential and GHG (Greenhouse Gas) Emissions Mitigation of Straw-Based Biomass Power Plant: A Case Study in Anhui Province, China," Processes, vol. 7, p. 608, 2019. DOI: 10.3390/pr7090608

[3] M. Castaldi, J. van Deventer, J. M. Lavoie, J. Legrand, A. Nzihou, Y. Pontikes, X. Py, C. Vandecasteele and P. T. Vasuedevan, "Progress and Prospects in the Field of Biomass and Waste to Energy and Added-Value Materials," Waste and Biomass Valorization, vol. 8, no. 6 , pp. $1875-1884$, 2017. DOI: $10.1007 / \mathrm{s} 12649$ 017-0049-0

[4] S. Jablonski, A. Pantaleo, A. Bauen, P. Pearson, C. Panoutsou and R. Slade, "The potential demand for bioenergy in residential heating applications (bioheat) in the UK based on a market segment analysis," Biomass and Bioenergy, vol. 32, no. 7, pp. 635-653, 2008. DOI: 10.1016/j.biombioe.2007.12.013

[5] A. Kozlov, O. Marchenko, and S. Solomin, "The modern state of wood biomass gasification technologies and their economic efficiency," Energy Procedia, vol. 158, pp. 1004-1008, 2019. https://doi. org/10.1016/j.egypro.2019.01.244

[6] A. Molino, S. Chianese, and D. Musmarra, "Biomass gasification technology: The state of the art overview," Journal of Energy Chemistry, vol. 25, no. 1, pp. 1025, 2016. DOI: 10.1016/j.jechem.2015.11.005

[7] A. A. Bhuiyan, A. S. Blicblau, A. K. M. Sadrul Islam and J. Naser, "A review on thermo-chemical characteristics of coal/biomass co-firing in industrial furnace," Journal of the Energy Institute, vol. 91, no. 1, pp. 1-18, 2018. DOI: 10.1016/j.joei.2016.10.006

[8] A. D. Kamble, V. K. Saxena, P. D. Chavan, and V. A. Mendhe, "Co-gasification of coal and biomass an emerging clean energy technology: Status and prospects of development in the Indian context," International Journal of Mining Science and Technology, vol. 29, no. 2, pp. 171-186, 2019. DOI: 10.1016/j.ijmst.2018.03.011

[9] P. R. Bhoi, R. L. Huhnke, A. Kumar, N. Indrawan and S. Thapa, "Co-gasification of Municipal Solid Waste and Biomass in a Commercial Scale Downdraft Gasifier," Energy, vol. 163, pp. 513-518, 2018. DOI: 10.1016/j.energy.2018.08.151

[10] M. Hupa, O. Karlstrom and E. Vainio, "Biomass combustion technology development - It is all about chemical details," Proceedings of the Combustion Institute, vol. 36, no. 1, pp. 113-134, 2017. DOI: 10.1016/j.proci.2016.06.152

[11] Coal and biomass gasification. Recent advances and future challenges, S. De, A.K. Agarwal, V.S. Moholkar and B. Thallada, eds. Singapore: Springer, 2018. DOI: 10.1007/978-981-10-7335-9

[12] E. Madadian, "Experimental Observation on Downdraft Gasification for Different Biomass Feedstocks" in Gasification for Low-Grade Feedstock, Rjieka: InTech, 2018, pp. 79-93. DOI: 10.5772/ intechopen.77119

[13] H. Tolvanen, T. Keipi, and R. Raiko, "A study on raw, torrefied, and steam-exploded wood: Fine grinding, drop-tube reactor combustion tests in $\mathrm{N} 2 / \mathrm{O} 2$ and $\mathrm{CO} 2 / \mathrm{O} 2$ atmospheres, particle geometry analysis, and numerical kinetics modeling," Fuel, vol. 176, pp. 153164, 2016. DOI: 10.1016/j.fuel.2016.02.071

[14] T. Kan, V. Strezov and T.J. Evans, "Lignocellulosic biomass pyrolysis: A review of product properties and effects of pyrolysis parameters," Renewable and Sustainable Energy Reviews, vol. 57, pp. 1126-1140, 2016. DOI: 10.1016/j.rser.2015.12.185

[15] A. Akhtar, V. Krepl and T. Ivanova, "A Combined Overview of Combustion, Pyrolysis, and Gasification of Biomass," Energy Fuels, vol. 32, no. 7, pp. 72947318, 2018. DOI: 10.1021/acs.energyfuels.8b01678

[16] M. Kortelainen, J. Jokiniemi, P. Tiltta, J. Tissari, H. Lamberg, J. Leskinen, J.G.-L. Rodriguez, H. Koponen, S. Antikanen, I. Nuutinen, R. Zimmermann and O. Sippula, "Time-resolved chemical composition of small-scale batch combustion emissions from various wood species," Fuel, vol. 233, pp. 224-236, 2018. DOI: 10.1016/j.fuel.2018.06.056

[17] S. Heidenreich and P.U. Foscolo,"New concepts in biomass gasification," Progress in Energy and Combustion Science, vol. 46, pp. 72-95, 2015. DOI: 10.1016/j.pecs.2014.06.002

[18] S. K. Sansaniwal, M. A. Rosen and S. K. Tyagi, "Global challenges in the sustainable development of biomass gasification: An overview," Renewable and Sustainable Energy Reviews, vol. 80, pp. 23-43, 2017. 
[19] I. Hirka, O. Zivny, and M. Hrabovsky, "Numerical Modelling of Wood Gasification in Thermal Plasma Reactor," Plasma Chemistry and Plasma Processing, vol. 34, pp. 947-965, 2017. DOI: 10.1007/s11090017-9812-z

[20] O. Yakaboylu, I. Albrecht, J. Harinck, K.G. Smit, G.A. Tsalidis, M. Di Marcello, K. Anastasakis and W. de Jong, "Supercritical water gasification of biomass in fluidized bed: First results and experiences obtained from TU Delft/Gensos semi-pilot scale setup," Biomass and Bioenergy, vol. 111, pp. 330-342, 2018. DOI: 10.1016/j.biombioe.2016.12.007

[21] K. B. Sutar, S. Kohli, M. R. Ravi, "Design, development, and testing of small downdraft gasifiers for domestic cookstoves," Energy, vol. 124, pp. 447460, 2017. DOI: 10.1016/j.energy.2017.02.076

[22] A. A. P. Susastriawan, H. Saptoadi, and Purnomo, "Small-scale downdraft gasifiers for biomass gasification: A review," Renewable and Sustainable Energy Reviews, vol. 76, pp. 989-1003, 2017. DOI: 10.1016/j.rser.2017.03.112

[23] E. Elsner, M. Wysocki, P. Niegodajew and R. Borecki, "Experimental and economic study of small-scale CHP installation equipped with downdraft gasifier and internal combustion engine," Applied Energy, vol. 202, pp. 213-227, 2017. DOI: 10.1016/j. apenergy.2017.05.148

[24] N. Indrawan, S. Thapa, P. R. Bhoi, R. L. Huhnke, and A. Kumar, "Engine power generation and emission performance of syngas generated from low-density biomass," Energy Conversion and Management, vol. 148, pp. 593-603, 2017. DOI: 10.1016/j. enconman.2017.05.066

[25] M. Renzi, C. Riolfi and M. Baratieri, "Influence of the syngas feed on the combustion process and performance of a micro gas turbine with steam injection," Energy Procedia, vol. 105, pp. 1665-1670, 2017. DOI: 10.1016/j.egypro.2017.03.543

[26] R. O. Gadsboll, A. V. Garcia, J. Ahrenfeldt and U. B. Henriksen, "Solid oxide fuel cell stack coupled with an oxygen-blown TwoStage gasifier using minimal gas cleaning," Renewable Energy, vol. 139, pp. 12551262, 2019. DOI: 10.1016/j.renene.2019.03.038

[27] I. Obernberger, T. Brunner, C. Mandl, M. Kerschbaum and T. Svetik, "Strategies and technologies towards zero-emission biomass combustion by primary measures," Energy Procedia, vol. 120, pp. 681-688, 2017. DOI: 10.1016/j.egypro.2017.07.184

[28] C. Y. Li, J. Y. Wu, C. Chavasint, S. Sampattagul, T. Kiatsiriroat, and R. Z. Wang, "Multi-criteria optimization for a biomass gasification-integrated combined cooling, heating, and power system based on life-cycle assessment," Energy Conversion and Management, vol. 178, pp. 383-399, 2018. DOI: 10.1016/j.enconman.2018.10.043

[29] F. Ardolino, C. Lodato, T. F. Astrup, U. Arena, "Energy recovery from plastic and biomass waste by means of fluidized bed gasification: A life cycle inventory model," Energy, vol. 165B, pp. 299-314, 2018.
[30] S. A. Kalogirou, "Solar thermal collectors and applications," Progress in Energy and Combustion Science, vol. 30, no. 3, pp. 231-295, 2004. DOI: 10.1016/j.pecs.2004.02.001

[31] Y. Tian and C. Y. Zhao, "A review of solar collectors and thermal energy storage in solar thermal applications," Applied Energy, vol. 104, pp. 538-553, 2013. DOI: 10.1016/j.apenergy.2012.11.051

[32] E. Gonzalez-Roubaud, D. Perez-Osorio, and C. Prieto, "Review of commercial thermal energy storage in concentrated solar power plants: Steam vs. molten salts," Renewable and Sustainable Energy Reviews, vol. 80, pp. 133-148, 2017. DOI: $10.1016 /$ j. rser.2017.05.084

[33] A. Gonzalez, J.-R. Riba and A. Rius, "Optimal sizing of a hybrid grid-connected photovoltaic-windbiomass power system," Sustainability, vol. 7, pp. 12787-12806, 2015. DOI: 10.3390/su70912787

[34] M. Suarez-Almeida, A. Gomez-Barea, A. F. Ghoniem, and C. Pfeifer, "Solar gasification of biomass in a dual fluidized bed," Chemical Engineering Journal, vol. 406, paper no. 126665 , 2020. DOI: $10.1016 / \mathrm{j}$. cej. 2020.126665

[35] D. N. Karamov, "Integration of the storage battery categorization process into the task of optimizing the equipment of stand-alone energy systems with renewable energy sources," Bulletin of the Tomsk Polytechnic University. Geo Assets Engineering, vol. 330, no 5, pp. 113-130, 2019. DOI: 10.18799/24131830/2019/5/262

[36] D. Sidorov, D. Panasetsky, N. Tomin, D. Karamov, A. Zhukov, I. Muftahov, A. Dreglea, F. Liu and Y. Li, "Toward Zero-Emission Hybrid AC/DC Power Systems with Renewable Energy Sources and Storages: A Case Study from Lake Baikal Region," Energies, vol. 13, paper no. 1226, 2020. DOI: 10.3390/en13051226

[37] T. Kodama, "High-temperature solar chemistry for converting solar heat to chemical fuels," Progress in Energy and Combustion Science, vol. 29, no. 6, pp. 567-597, 2003. DOI: 10.1016/S0360-1285(03)000595

[38] R. Bader and W. Lipinski, "Solar thermal processing," in Advances in Concentrating Solar Thermal Research and Technology, Elsevier, 2017, pp. 403-459. DOI: 10.1016/B978-0-08-100516-3.00018-6

[39] M. Puig-Arnavat, E. A. Tora, J.C. Bruno, and A. Coronas, "State of the art on reactor designs for solar gasification of carbonaceous feedstock," Solar Energy, vol. 97, pp. 67-84, 2013. DOI: 10.1016/j. solener.2013.08.001

[40] M. Kruesi, Z. R. Jovanovic and A. Steinfeld, "A twozone solar-driven gasifier concept: Reactor design and experimental evaluation with bagasse particles," Fuel, vol. 117, pp. 680-687, 2014. DOI: 10.1016/j. fuel.2013.09.011

[41] H. Boujjat, S. Rodat, S. Chuayboon, and S. Abanades, "Numerical simulation of reactive gas-particle flow in a solar jet spouted bed reactor for continuous biomass 
gasification," International Journal of Heat and Mass Transfer, vol. 144, paper no. 118572, 2019. DOI: 10.1016/j.ijheatmasstransfer.2019.118572

[42] P. von Zedtwitz and A. Steinfeld, "The solar thermal gasification of coal - energy conversion efficiency and CO2 mitigation," Energy, vol. 28, pp. 441-456, 2003. DOI: 10.1016/S0360-5442(02)00139-1

[43] A. P. Muroyama, I. Guscetti, G. L. Schieber, S. Haussener and P. G. Loutzenhiser, "Design and demonstration of a prototype $1.5 \mathrm{~kW}$ th hybrid solar/ autothermal steam gasifier," Fuel, vol. 211, pp. 331340, 2018. DOI: 10.1016/j.fuel.2017.09.059

[44] O. V. Marchenko and S. V. Solomin, "Matematicheskoe modelirovanie avtonomnoi sistemy elektrosnabzheniya s gazogeneratornoi elektrostantsiei [Mathematical modelling of autonomous power supply system with gasifier power station]" Information and Mathematical Technologies in Science and Control. Proceedings of the 13th Baykal Conference, Irkutsk: MESI SB RAS, vol. 1, pp. 14-19, 2008.

[45] M. Rokni, "Biomass gasification integrated with a solid oxide fuel cell and Stirling engine," Energy, vol. 77, pp. 6-18, 2014. DOI: 10.1016/j.energy.2014.01.078

[46] D. Popov, "An option for solar thermal repowering of fossil fuel-fired power plants," Solar Energy, vol. 85 , no. 2, pp. 344-349. 2011. DOI: $10.1016 /$ j. solener.2010.11.017

[47] J. H. Lim, A. Chinnici, B. B. Dally, and G. J. Nathan, "Assessment of the potential benefits and constraints of a hybrid solar receiver and combustor operated in the MILD combustion regime," Energy, vol. 116(1), pp. 735-745, 2016. DOI: 10.1016/j.energy.2016.10.017

[48] V. Pozzobon, S. Salvador, and J.J. Bezian, "Biomass gasification under high solar heat flux: Experiments on thermally thick samples," Fuel, vol. 174, pp. 257 266, 2016. DOI: 10.1016/j.fuel.2016.02.003

[49] S. Chuayboon, S. Abanades and S. Rodat, "Comprehensive performance assessment of a continuous solar-driven biomass gasifier," Fuel Processing Technology, vol. 182, pp. 1-14. 2018. DOI: 10.1016/j.fuproc.2018.10.016

[50] A. S. Zaitsev, R. I. Egorov, and P. A. Strizhak, "Lightinduced gasification of the coal-processing waste: Possible products and regimes," Fuel, vol. 212, pp. 347-352, 2018. DOI: 10.1016/j.fuel.2017.10.058

[51] S. Sobek and S. Werle, "Kinetic modeling of waste wood devolatilization during pyrolysis based on thermogravimetric data and solar pyrolysis reactor performance," Fuel, vol. 261, paper no. 116459, 2020. DOI: 10.1016/j.fuel.2019.116459

[52] P. G. Loutzenhiser and A. P. Muroyama, "A review of the state-of-the-art in solar-driven gasification processes with carbonaceous materials," Solar Energy, vol. 156, pp. 93-100, 2017. DOI: 10.1016/j. solener.2017.05.008

[53] W. Lipinski and A. Steinfeld, "Transient radiative heat transfer within a suspension of coal particles undergoing steam gasification," Heat and Mass
Transfer, vol. 41, no. 11, pp. 1021-1032, 2005. DOI: 10.1007/s00231-005-0654-5

[54] N. Piatkowski and A. Steinfeld, "Solar gasification of carbonaceous waste feedstocks in a packedbed reactor - Dynamic modeling and experimental validation," American Institute of Chemical Engineers Journal, vol. 57, no. 12, pp. 3522-3533, 2011. https:// doi.org/10.1002/aic.12545

[55] V. M. Wheeler, R. Bader, P. B. Kreider, M. Hangi, S. Haussener and W. Lipinski, "Modelling of solar thermochemical reaction systems," Solar Energy, vol. 156, pp. 149-168, 2017. DOI: $10.1016 / \mathrm{j}$. solener.2017.07.069

[56] J. Soria, K. Zheng, D. Asensio, D. Gauthier, G. Flamant and G. Mazza, "Comprehensive CFD modeling of solar fast pyrolysis of beech wood pellets," Fuel Processing Technology, vol. 158, pp. 226-237, 2017. DOI: 10.1016/j.fuproc.2017.01.006

[57] S. Bellan, N. Gokon, K. Matsubara, H.S. Cho, and T. Kodama, "Heat transfer analysis of $5 \mathrm{~kW}$ th circulating fluidized bed reactor for solar gasification using concentrated Xe light radiation," Energy, vol. 160, pp. 245-256, 2018. DOI: 10.1016/j.energy.2018.06.212

[58] M. R. Gomaa, R. J. Mustafa and N. Al-Dmour, "Solar thermochemical conversion of carbonaceous materials into syngas by Co-Gasification," Journal of Cleaner Production, vol. 248, paper no. 119185, 2020. DOI: 10.1016/j.jclepro.2019.119185

[59] K. Umeki, K. Yamamoto, T. Namioka and K. Yoshikawa, "High-temperature steam-only gasification of woody biomass," Applied Energy, vol. 87, pp. 791-798, 2010. DOI: 10.1016/j. apenergy.2009.09.035

[60] P. Lamarche, M. Tazerout, F. Gelix, S. Kohler, K. Mati, and F. Paviet, "Modelling of an indirectly heated fixed bed pyrolysis reactor of wood: Transition from batch to continuous staged gasification," Fuel, vol. 106, pp. 118-128, 2013. DOI: 10.1016/j.fuel.2012.12.005

[61] M. Mayerhofer, P. Mitsakis, X. Meng, W. de Jong, H. Spliethoff and M. Gaderer, "Influence of pressure, temperature and steam on tar and gas in allothermal fluidized bed gasification," Fuel, vol. 99, pp. 204-209, 2012. DOI: 10.1016/j.fuel.2012.04.022

[62] A. N. Brattsev, V. A. Kuznetsov, V. E. Popov, and A. A. Ufimtsev, "Arc gasification of biomass: example of wood residue," High Temperature, vol. 49, no. 2, pp. 244-248, 2011. DOI: 10.1134/S0018151X11010020

[63] K. Qin, W. Lin, P. A. Jensen, and A. D. Jensen, "Hightemperature entrained flow gasification of biomass," Fuel, vol. 93, pp. 589-600, 2012. DOI: 10.1016/j. fuel.2011.10.063

[64] J. Stasiek, M. Jewartowski and W. Yang, "Small Scale Gasification of Biomass and Municipal Wastes for Heat and Electricity Production using HTAG Technology," E3S Web of Conference, vol. 13, paper no. 03005,2017 . DOI: $10.1051 / \mathrm{e} 3$ sconf $/ 20171303005$

[65] C. Freda, F. Nanna, A. Villone, D. Barisano, S. Brandani, and G. Cornacchia, "Air gasification of digestate and its co-gasification with residual biomass 
in a pilot-scale rotary kiln," International Journal of Energy and Environmental Engineering, vol. 10, pp. 335-346, 2019. DOI: 10.1007/s40095-019-0310-3

[66] F. Campuzano, R. C. Brown and J. D. Martinez, "Auger reactors for pyrolysis of biomass and wastes," Renewable and Sustainable Energy Reviews, vol. 102, pp. 372-409, 2019. DOI: 10.1016/j.rser.2018.12.014

[67] J. Chojnacki, J. Najser, K. Rokosz, V. Peer, J. Kielar, and B. Berner, "Syngas composition: gasification of wood pellet with water steam through a reactor with continuous biomass feed system," Energies, vol. 13, paper no. 4376, 2020. DOI: 10.3390/en13174376

[68] W. F. Fassinou, L. Van de Steene, S. Toure, G. Volle, and P. Girard, "Pyrolysis of Pinus pinaster in a twostaged gasifier: Influence of processing parameters and thermal cracking of tar," Fuel Processing Technology, vol. 90, pp. 75-90, 2009. DOI: 10.1016/j. fuproc.2008.07.016

[69] R. O. Gadsboll, L. R. Clausen, T. P. Thomsen, J. Ahrenfeldt and U. B. Henriksen, "Flexible TwoStage biomass gasifier designs for polygeneration operation,” Energy, vol. 166, pp. 939-950, 2019. DOI: 10.1016/j.energy.2018.10.144

[70] J. Ran and C. Li, "High-temperature gasification of woody biomass using regenerative gasifier," Fuel Processing Technology, vol. 99, pp. 90-96, 2012. DOI: 10.1016/j.fuproc.2012.01.002

[71] K. Umeki, T. Namioka and K. Yoshikawa, "Analysis of an updraft biomass gasifier with high-temperature steam using a numerical model," Applied Energy, vol. 90, no. 1, pp. 38-45, 2012. DOI: $10.1016 /$ j. apenergy.2010.12.058

[72] P. Lamarche, M. Tazerout, F. Gelix, S. Kohler, K. Mati, and F. Paviet, "Modelling of an indirectly heated fixed bed pyrolysis reactor of wood: Transition from batch to continuous staged gasification," Fuel, vol. 106, pp. 118-128, 2013. DOI: 10.1016/j.fuel.2012.12.005

[73] T. M. Ismail and M. A. El-Salam, "Parametric studies on biomass gasification process on updraft gasifier high-temperature air gasification," Applied Thermal Engineering, vol. 112, pp. 1460-1473, 2017. DOI: 10.1016/j.applthermaleng.2016.10.026

[74] I. G. Donskoi, A. N. Kozlov, D. A. Svishchev and V. A. Shamanskii, "Numerical investigation of the staged gasification of wet wood," Thermal Engineering, vol. 64, no. 4, pp. 258-264, 2017. DOI: 10.1134/ S0040601517040024

[75] A. Levin, A. Kozlov, D. Svishchev and M. Penzik, "Verification of the heat transfer model for screw reactor," MATEC Web of Conferences, vol. 240, paper no. 05017, 2018. DOI: 10.1051/ matecconf/201824005017

[76] D. A. Frank-Kamenetskii, Diffusion and Heat Exchange in Chemical Kinetics, Princeton Univ. Press, 2015.

[77] V. I. Kovenskii, "Method of calculating the bed combustion of a solid fuel coke residue," Theoretical Foundations of Chemical Engineering, vol. 46, no. 2, pp. 180-192, 2012.
[78] I. G. Donskoy, "Process simulation of the cogasification of wood and polymeric materials in a fixed," Solid Fuel Chemistry, vol. 52, no 2, pp. 121127, 2018. DOI: 10.3103/S0361521918020027

[79] I. G. Donskoy, "Mathematical modeling of coal and sewage sludge co-conversion using downdraft gasifier," Bulletin of the Tomsk Polytechnic University. Geo Assets Engineering, vol. 330, no. 2, pp. 7-18, 2019. DOI: 10.18799/24131830/2019/2/89

[80] A. D. Nikitin, G. I. Nikitina, S. V. Buinachev, and A. F. Ryzhkov, "Effect of steam conversion parameters on the activated coal characteristics," AIP Conference Proceedings, vol. 2015, paper no. 020064, 2018. DOI: $10.1063 / 1.5055137$

[81] A. V. Keiko, D. A. Svishchev and A. N. Kozlov, Gasification of low-grade fuels: state of the art and perspectives of technologies, Irkutsk: MESI SB RAS, 2007.

[82] H. Boujjat, S. Rodat and S. Abanades, "Solar-hybrid Thermochemical Gasification of Wood Particles and Solid Recovered Fuel in a Continuously-Fed Prototype Reactor," Energies, vol. 13, paper no. 5217, 2020. DOI: $10.3390 /$ en13195217

[83] L. Arribas, N. Arconada, C. Gonzalez-Fernandez, C. Lohrl, J. Gonzalez-Aguilar, M. Kaltschmitt, and M. Romero, "Solar-driven pyrolysis and gasification of low-grade carbonaceous materials," International Journal of Hydrogen Energy, vol. 42, no. 19, pp. 1359813606, 2017. DOI: 10.1016/j.ijhydene.2017.02.026

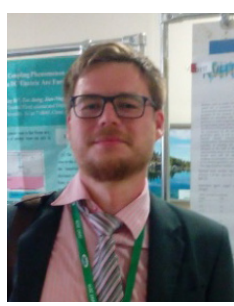

Igor Donskoy received the Ph.D. degree in energy systems in 2014. He is currently a senior researcher in the Laboratory of Thermodynamics at Melentiev Energy Systems Institute SB RAS (Irkutsk). His main research interests include mathematical modeling, fuel processing, and thermal engineering. 